\title{
Material Teaching Aids: Enhancement Tool for Teaching Essay Writing in Secondary Schools
}

\author{
Okonkwo Adaobi Fidelia, ${ }^{1, *}$ \\ ${ }^{1}$ Department of Arts and Social Science Education, Faculty of Education, Ebonyi State University, Abakaliki, Nigeria \\ *Correspondence: Department of Arts and Social Science Education, Faculty of Education, Ebonyi State University, \\ Abakaliki, Nigeria. Tel: 234-80-3540-1195 E-mail: addyfidel@gmail.com
}

Received: August 26, 2015

Accepted: September 24, $2015 \quad$ Online Published: October 11, 2015

doi:10.5430/wje.v5n5p110

URL: http://dx.doi.org/10.5430/wje.v5n5p110

\begin{abstract}
The purpose of this study is to investigate the use of material teaching aids as enhancement tool for teaching essay writing in secondary schools in Ebonyi State. A 4-point Likert-scale questionnaire was used as the instrument. A trial test was conducted and tested for reliability and a value of 0.75 was obtained from the test. The instrument was further subjected to face validation. The population comprised of 1553 language teachers - English, Literature, Igbo and French and out of this number 240 teachers were selected using simple random sampling technique and it was done to reflect male and female teachers - 120 males and 120 females. Mean and standard deviation were used to answer the research questions while Analysis of Covariance ANCOVA was used to test the hypothesis at an alpha level 0.05 of significance. Result obtained from the data indicated that (1) Most material teaching aids are not available in schools (2) teaching of essay writing requires application of effective material teaching aids. (3) most teachers do not teach essay and do not apply the use of material teaching aids. Male and female teachers are not different in application of material teaching aids in teaching essay writing. It was therefore recommended that (1) careful plan of essay writing using effective material teaching aids should be done. (2)Teachers should be resourceful enough to create improvised materials teaching aids. (3) school authorities and the government should help in procuring material teaching aids in secondary schools to enhance learning of essay writing.
\end{abstract}

Keywords: essay writing; material teaching aids; improvisation; procurement; enhancement; teaching

\section{Introduction}

Language is a veritable tool for knowledge impartation. The basic role of language is for communication. Language such as the English language is a universal language. The English language occupies a unique place in Nigeria education system because of its significant role and status in the country's national life. English is important in Nigeria because it has become over the years, language of official, business and a vital link between the various ethnic groups in the country.

The English language is also pedagogically important as the language of instruction in virtually the entire school system in Nigeria. Baldeh (2004) attests that good educational system should equip its products to communicate adequately, expressing their thoughts, opinions, emotions, attitudes, clearly in an organized manner. Aliyu (2006:133) emphatically stresses that:

English is in effect, the second language of Nigeria, essential for success in the educational life. It is not surprising therefore, that so much attention and resources have been and continue to be devoted to its teaching in Nigerian schools, and it is likely to continue for many years to come.

The senior school certificate examination (SSCE) syllabus shows that English is categorized into; lexis and structure, summary and comprehension, essay and letter writing and oral English. Mastery in the first three categories ensures good performance in the art of speech and writing.

Essay writing is an indispensable skill of art which demands that students should organize their thoughts clearly and effectively. Hornby (2004) sees writing as the activity of writing in contrast to reading. Azikiwe (1998) observes that writing a long essay is probably the most complex constructive art that most human beings are ever expected to study. 
Ghaith (2006) sees essay writing as a complex process that allows writers to explore thoughts and ideas and make them visible and concrete. Banjo and Bisong (2005) identify qualities of a good essay as grammatical accuracy, unity, topic sentence and coherence.

Essay writing according to Obah (2005), is a deliberate development in clear and well reasoned prose of one or more ideas through several paragraphs to achieve a desired effect upon a known audiences. The effect brings the reader's understanding to the writer's point of view. Also (Ogbu, 2009:87) further views essay writing as "an art of creativity and imaginatively putting down one's ideas, feeling and opinion in writing. There are different types of essay. Narrative essay is one that relates to series of events or telling a story which uses a device to explain an idea when anecdote is introduced. Descriptive essay is one that tells what something is like and the description may be either about a concrete object such as a scene or a person or about an abstract idea such as fear. Argumentative essay is one which devotes to arguing out an issue, ideally looking at both sides of the argument and coming to such rational and logical conclusion. While expository essay is one that deals with explanations or exposition essay is one that deals with explanation or exposition of information and ideal, it illustrates, defines, compares and explains by careful selection of relevant materials, orderly presentation and coherent argument (Chima, Nweke, Onwe and Ugwuagbo, 2005). Essay writing is an essential aspect of the English language as it makes a child to attain intellectual and emotional development. Through essay the child expresses his/her feeling, needs, knowledge and interest.

For students to make good grades in English it is expected that they should be grounded in the skill of writing. The Federal Republic of Nigeria (FRN) in the National Policy on Education (2004) states that English language is a core subject to study in Nigerian secondary schools and a medium for education in Nigeria. This cannot be achieved without effective writing and it forms a greater percentage of about $40 \%$ out of $100 \%$ allotted to the whole aspects of English. Poor performance in essay writing indicates poor performance in the English language.

Although essay writing is a principal tool that students employ in learning, communication and assessment, yet most students find it very difficult and this affects their overall performance in the English language. Students' incompetency in the skill of writing are manifested in their past essay writing for many years as they are inadequately exposed to the skill of writing, lack of peculiarities with the required formats, construction of loose sentences, transliteration from the mother tongue and abuse of the basic rules of grammar. It was further noted that students scored zero under mechanical accuracy aspect of the essay (West African Senior School Certificate Chief Examiners' report, 2009).

This demeaning performance of students may be as a result of poor teaching method most teachers adopt in teaching essay writing in schools. Most teachers do not seem to use material teaching aids. There is the view that sex makes a difference as conceived by Eze (2009) that girls develop better attitude to language and communication especially in essay writing than boys while Otagburuagu (2002) believes that what makes the difference in the academic achievement of people is that some individuals have exceptional verbal aptitude which makes it possible for them to begin to use a language and begin to use it within a short period of learning to interact in the appropriate situation. This maybe applicable in the way male and female teachers apply the use of material teaching aids in teaching essay writing.

Hence, the students find it difficult to form basic concepts, think, plan, and write coherently in English. The focal point of this paper is to view the importance of material teaching aids in essay writing.

\subsection{Material Teaching Aids and Essay Writing}

Material teaching aids can refer to all forms of information carriers, which can be used to record, store, preserve, transmit or retrieve information for the purpose of teaching and learning. It can also be seen as all those instruments teachers use in the classroom for teaching (Azikiwe, 1998; Akinbola, 2009). Absence of material teaching aids in most schools constitute problem for effective teaching and learning in schools especially in essay writing. Chukwu (2007: 200) emphasizes the importance of instructional materials by stating that "the purpose or need of charts is to present visual ideas or concepts which are likely to be difficult to understand if presented in oral or written form". Through posters, students develop useful learning experiences, photograph, magazines, and pictures are useful instructional materials. Flat pictures with key notes motivate the study of new topics and it is used to communicate basic information and most importantly to evaluate students' achievement before or after instruction (Chukwu, 2007). Unfortunately, most material teaching aids are not available in schools. Most available textbooks are obsolete (Offorma, 2009). Ugwu in Okonkwo (2014) states that in Nigeria, teachers scarcely teach with materials due to various factors such as unavailability of teaching materials, poor teaching and training. They further maintain that well trained teacher should be able to design and produce materials that will meet the characteristics of the learners and relevant to the objective. Essay writing especially should be taught to students using relevant and effective instructional materials. For example textbooks which contain a particular or related essay topic can be assigned to students to read in advance. This can make students to have an idea of the contents of the essay topic. The teacher at 
the onset of teaching can help students to brainstorm on the point needed in writing the essay, he/she may have prepared material aids before hand by using for example; cardboard sheet to write out each point which the teacher had already converted to topic sentences. The teacher releases and shows each point to students and makes the students develop supporting details on each topic sentence. She could allow individual student to develop it as a topic sentence which forms paragraph. Each paragraph should be introduced and linked to the other paragraph using appropriate transitional words, such as, also, again, in addition, moreover, furthermore, etc. the teacher uses flash cards bearing different transitional words to emphasize the need and how it may be used to introduce each as a fresh point or idea. The teacher assigns the students to write on the topic of the essay, marks and can decide to read out the best essays produced by students in the class and points out why some of the essays are poorly written. The teacher can as well, use flannel board to indicate vital areas of the essay and uses colours to indicate them. Also, the essay can be read out, taped and played before the students while the teacher points out and emphasizes on the important parts of the essay.

Because of important nature of essay writing especially in the senior secondary schools, material teaching aids such as books, charts, print out materials are likely to enhance essay writing. Azikiwe (1998) notes that in the teaching profession, that textbooks are regarded as instructional aids which are sinequa- non in teaching and learning processes. Textbooks and other instructional materials such as news papers and magazines, journals and other publications help both the teacher and students to have better and quicker understanding on what they teach. Azikiwe (1998) further notes that material teaching aids generally are essential ingredients for teaching especially essay writing and they are powerful source of motivation. Instructional materials are classified into three categories: (i) graphic and non projected materials (ii) projected materials and (iii) audio materials and equipment. Brown (1998) explains visual instructional materials as: sight enhanced and oriented materials such as pictures, objects, specimen, textbooks, blackboards, bulletin boards and other printed and projected materials or any other visuals. Teachers must know the advantage and limitations of each type of instructional media and be disposed, like any craft man, to select from this whole array of tools and devices or combination of devices which best serve in mediating teaching purpose (Eje, 2000).

Students are exposed to reading through the use of library and this enhances their writing ability. Other teaching aids such as picture of a thing, a person or a place can increase descriptive ability of students. Essay writing requires planning which should involve selecting a topic, forming a point of view, searching for facts, selecting, organizing and analyzing the facts as well as drawing up an outline. The teacher needs to back up these pre-writing stages with adequate and effective instructional materials step by step as these give wider thought provoking ideas and concretize learning. When one has a point of view fixed in his mind, he may search for supporting facts from two sources - private source of one's direct experiences and the public source of books, magazines, articles and report; oral or written (Obah,2006). It is therefore necessary that the teacher acquires and handles the right teaching aids in such a way that it will facilitate effective learning of essay writing.

\subsection{Research Questions}

The following research questions were formed to guide the study:

1. What are the material teaching aids that are available in teaching essay writing in schools?

2. How would effective application of material teaching aids in essay writing be?

3. How do teachers apply material teaching aids in essay writing in schools?

\subsection{Hypothesis}

H01: There is no significant difference in male and female teachers' application of material teaching aids in teaching essay writing.

\section{Methodology}

\subsection{Design of the Study}

The researcher adopted descriptive survey design. Data were generated from questionnaire responses titled "material teaching aids and effective application questionnaire". The instrument was further subjected to reliability test using Crombach alpha method and a value of 0.75 was obtained as the reliability of the instrument and this warranted the use of the instrument. The questionnaire was divided into four sections and each section contained sub-title of the twenty- four questionnaire items which were generated based on a 4-point scale - strongly agree (4), agree (3), disagree (2), and strongly disagree (1). The respondents were asked to tick $(\sqrt{ })$ on the appropriate option. The 
instrument was subjected to face validation by experts in the field and a trial test was carried out. Based on the result, construct validation using factor analysis was carried out by experts and all the twenty-four items were isolated.

\subsection{Area of the Study and Sampling Technique}

The areas covered were the three Education zones in Ebonyi State. These are Abakaliki, Onueke and Afikpo in Ebonyi State of Nigeria. The population comprised of 1553 English language teachers. Simple random sample technique was used to select teachers which reflected male and female teachers. A total of 240 teachers were selected, 120 males and 120 females in English language, literature, Igbo and French teachers.

\subsection{Method of Data Collection}

240 questionnaire were taken to different schools and distributed to languages and literature teachers and on the spot distribution and collection were adopted to avoid mortality of the instrument and the instrument collected were used in the data analysis.

\subsection{Method of Data Analysis}

Mean and standard deviation were used to answer the research questions. Decision rule was based on the result of 2.5 and above as being high and anything below that as being low. The hypothesis generated was tested using t-test to identify if a significant difference existed or not in the responses of male and female teachers' application of material teaching aids in teaching essay writing.

\section{Results}

Data were presented based on the three research questions and a null hypothesis. Results were presented in accordance to the individual responses on the research questions and the hypothesis which guided this work. Serial number was assigned to each item and number of participants under $\mathrm{A}=$ Strongly Agree, $\mathrm{B}=$ Agree, $\mathrm{C}=$ Disagree and $\mathrm{D}=$ Strongly Disagree which accept or reject the item.

Table 1. Teachers' Mean Rating on Material Teaching Aids Available in Teaching Essay Writing in Schools

\begin{tabular}{lllllllll}
\hline S/N & Materials available in schools & SA & A & D & SD & $\bar{X}$ & SD & Remark \\
\hline 1 & Objects & 12 & 17 & 180 & 31 & 2.04 & 0.66 & Rejected \\
2 & Pictures of certain objects & 9 & 6 & 45 & 170 & 1.32 & 0.28 & Rejected \\
3 & Computer & 21 & 23 & 90 & 106 & 1.83 & 0.21 & Rejected \\
4 & Different textbooks on essay & 55 & 40 & 90 & 55 & 2.40 & 0.30 & Rejected \\
5 & Models & 2 & 10 & 121 & 107 & 1.62 & 0.44 & Rejected \\
6 & Projectors & 4 & 2 & 110 & 124 & 1.54 & 0.42 & Rejected \\
7 & Charts & 25 & 28 & 125 & 62 & 2.07 & 0.35 & Rejected \\
8 & Newspapers & 51 & 12 & 94 & 74 & 2.09 & 0.35 & Rejected \\
9 & Magazines & 24 & 28 & 104 & 84 & 1.97 & 0.25 & Rejected \\
10 & Maps \& gazetteers & 10 & 15 & 175 & 40 & 2.05 & 0.63 & Rejected \\
& Grand Total & & & & & $\mathbf{1 . 8 9}$ & & \\
\hline
\end{tabular}

Summary of result on table 1 above reveals that teachers' mean rating on material teaching aids available in schools are in very short supply. This to a great extent indicates that essay writing in schools are taught in abstraction to the disadvantage of the students.

Table 2. Opinion of Teachers on How Effective Application of Material Teaching Aids in Essay Writing Should Be

\begin{tabular}{|c|c|c|c|c|c|c|c|c|}
\hline $\mathrm{S} / \mathrm{N}$ & Effective application of material teaching aids in essay & SA & A & $\mathrm{D}$ & SD & $\overline{\mathrm{X}}$ & SD & Remark \\
\hline 1 & Searching for suitable materials & 180 & 52 & 4 & 4 & 3.70 & 1.41 & Accepted \\
\hline 2 & Pick relevant materials for illustrations & 204 & 30 & 4 & 2 & 3.91 & 1.62 & Accepted \\
\hline 3 & Assembles relevant ones & 180 & 53 & 3 & 4 & 3.71 & 1.41 & Accepted \\
\hline 4 & Organizes the materials in stages of teaching & 210 & 31 & 5 & 4 & 3.95 & 1.68 & Accepted \\
\hline 5 & Presents materials relevant after or within each teaching point & 120 & 125 & 3 & 2 & 3.48 & 1.01 & Accepted \\
\hline \multirow[t]{2}{*}{6} & $\begin{array}{l}\text { Presents the materials in a summary form after teaching to } \\
\text { concretize learning }\end{array}$ & 191 & 43 & 3 & 4 & 3.77 & 1.51 & Accepted \\
\hline & Grand Mean & & & & & 3.75 & & \\
\hline
\end{tabular}


Results on Table 2 shows that effective application of material teaching aids in essay writing should reflect the above and essay writing would be very easy to understand if teachers take time to organize and make effective application of teaching aids.

Table 3. How do Teachers Apply Effective Material Teaching Aids in Essay Writing in Schools

\begin{tabular}{|c|c|c|c|c|c|c|c|c|}
\hline $\mathrm{S} / \mathrm{N}$ & $\begin{array}{l}\text { Teachers' poor application of material } \\
\text { teaching aids in essay writing }\end{array}$ & SA & A & $\mathrm{D}$ & SD & $\overline{\mathrm{X}}$ & $\mathrm{SD}$ & Remark \\
\hline 1 & Teachers do not search for suitable materials & 80 & 55 & 55 & 50 & 2.61 & 0.61 & Accepted \\
\hline 2 & Present lesson in abstraction & 88 & 76 & 46 & 30 & 2.93 & 0.60 & Accepted \\
\hline 3 & Do not select relevant materials & 45 & 99 & 60 & 36 & 2.64 & 0.46 & Accepted \\
\hline 4 & $\begin{array}{l}\text { Do not organize relevant material aids for } \\
\text { teaching essay }\end{array}$ & 50 & 87 & 59 & 39 & 2.57 & 0.41 & Accepted \\
\hline 5 & $\begin{array}{l}\text { Teachers do not use materials aids for } \\
\text { instruction in essay writing }\end{array}$ & 126 & 90 & 14 & 10 & 3.39 & 0.97 & Accepted \\
\hline 6 & $\begin{array}{l}\text { Do not organize materials in stages for } \\
\text { teaching }\end{array}$ & 98 & 101 & 26 & 15 & 3.17 & 0.77 & Accepted \\
\hline 7 & $\begin{array}{l}\text { Do not present materials in bits during each } \\
\text { teaching points }\end{array}$ & 115 & 91 & 21 & 13 & 3.29 & 0.88 & Accepted \\
\hline \multirow[t]{2}{*}{8} & $\begin{array}{l}\text { Do not summarize essay writing using } \\
\text { materials for consolidation }\end{array}$ & 98 & 97 & 20 & 25 & 3.11 & 0.76 & Accepted \\
\hline & Grand Mean & & & & & 2.96 & & \\
\hline
\end{tabular}

Data on Table 3 indicates that teachers poorly apply material teaching aids and this makes students to perform very poorly in essay writing in secondary schools. The grand mean of 2.96 accepted the fact that teachers most often do not using material teaching aids in teaching essay writing.

Table 4. T-Test Statistic on Male And Female Teachers' Application of Material Teaching Aids in Essay Writing

\begin{tabular}{|c|c|c|c|c|c|c|c|c|c|}
\hline \multicolumn{2}{|l|}{$\mathrm{S} / \mathrm{N}$} & $\begin{array}{l}\text { Sex of } \\
\text { teachers }\end{array}$ & $\mathrm{N}$ & $\mathrm{Df}$ & $\bar{X}$ & SD & $\begin{array}{l}\text { t-cal } \\
\text { value }\end{array}$ & $\begin{array}{l}\text { t- critical } \\
\text { value }(0.05)\end{array}$ & Remark \\
\hline \multirow[t]{2}{*}{1} & \multirow{2}{*}{$\begin{array}{l}\text { Searching for suitable materials for } \\
\text { teaching essay }\end{array}$} & male & 120 & 118 & 2.27 & 1.19 & 0.632 & 0.561 & Reject \\
\hline & & female & 120 & 118 & 2.36 & 1.09 & 0.621 & & \\
\hline & \multirow{2}{*}{$\begin{array}{l}\text { Present material in abstraction while } \\
\text { teaching essay }\end{array}$} & male & 120 & 118 & 3.08 & 0.89 & 0.621 & 0.535 & Reject \\
\hline & & female & 120 & 118 & 2.77 & 1.13 & 2.410 & & \\
\hline & \multirow{2}{*}{$\begin{array}{l}\text { Select relevant materials for teaching essay } \\
\text { writing }\end{array}$} & male & 120 & 118 & 2.79 & 0.82 & 2.410 & 0.077 & Reject \\
\hline & & female & 120 & 118 & 2.48 & 1.05 & 2.532 & & \\
\hline & \multirow{2}{*}{ Do not select relevant materials } & male & 120 & 118 & 2.73 & 0.91 & 2.532 & 0.120 & Reject \\
\hline 4 & & female & 120 & 118 & 2.46 & 1.10 & 2.116 & & \\
\hline & \multirow{2}{*}{$\begin{array}{l}\text { Do not use material aids in teaching essay } \\
\text { writing }\end{array}$} & male & 120 & 118 & 3.61 & 0.49 & 2.116 & 0.135 & Reject \\
\hline & & f & 120 & 118 & 3.16 & 0.94 & 4.670 & & \\
\hline \multirow[t]{2}{*}{6} & \multirow{2}{*}{$\begin{array}{l}\text { Do not present materials aids bit by bit } \\
\text { while teaching essay }\end{array}$} & male & 120 & 118 & 3.51 & 0.54 & 4.670 & 1.020 & Reject \\
\hline & & female & 120 & 118 & 3.06 & 1.02 & 4.297 & & \\
\hline \multirow[t]{2}{*}{7} & \multirow{2}{*}{$\begin{array}{l}\text { Do not summarize essay writing using } \\
\text { material aids }\end{array}$} & male & 120 & 118 & 3.34 & .66 & 4.297 & 0.410 & Reject \\
\hline & & & 120 & 118 & 2.89 & 1.13 & 3.778 & & \\
\hline \multirow[t]{2}{*}{8} & \multirow{2}{*}{$\begin{array}{l}\text { Do not organize materials for teaching } \\
\text { essay }\end{array}$} & male & 120 & 118 & 3.38 & 0.61 & 3.778 & 1.071 & Reject \\
\hline & & female & 120 & 118 & 2.98 & 1.02 & 3.698 & & \\
\hline
\end{tabular}

Data on Table 4 show that t-cal values in all the items show no significant difference in male and female application of material teaching aids in essay writing. In other words, both male and female teachers show the same attitude of not applying material teaching aids in essay writing.

\subsection{Findings}

The findings of the study were based on the three research questions and a null hypothesis that guided this work. The findings of the study were as follow:

1. Most material teaching aids are not available in most schools. 
2. Essay writing requires effective application of material teaching aids.

3. Most teachers do not apply material teaching aids in teaching essay writing.

4. Male and female teachers treat application of material teaching aids in essay writing in the same manner.

\subsection{Discussion}

Table 1 reveals that material teaching aids are not available in most secondary schools. Material resources such as pictures, different objects, computer, different textbooks and models have means of 2.04, 1.32, 1.83, 2.40 and 1.62 respectively. Other material teaching aids have mean as: projectors 1.54 , charts 2.07 , Newspapers 2.09 . The findings of the above learnt support to Offorma (2009) who noted that most of the instructional materials are not available in schools and that most available textbooks in the libraries are obsolete.

Table 2 reveals what how effective application of material teaching aids especially in essay writing should be, searching for suitable facts has mean of 3.70, pick relevant materials for illustration 3.91, assemble relevant materials 3.7, organizes the materials in stages of teaching 3.95, presents relevant materials after or within each teaching point 3.48 and presents the material aids in a summary that concretizes learning 3.77. This is in line with Obah (2006) who stated that essay writing requires planning which involves selecting a topic, forming a point of view, searching for facts, analyzing and arranging the fact. The scholar further stated that when one has a point of view fixed in his mind, he may search for supporting facts from two sources - private source of one's direct experiences and the public source of books, magazines articles and report, oral or written. This support needs to come from the teacher.

Table 3 reveals how teachers apply material teaching aids in teaching essay writing in schools. Searching for suitable materials has mean of 3.1, present lesson in abstraction 2.93, do not select relevant materials 2.64, do not organize material aids for instruction 2.57, do not organize materials in stages 3.17, do not present materials in bits during teaching points 3.29 and do not summarize essay writing using materials for consolidation 3.11. This findings is in line with Ugwu in Okonkwo (2014) who states that teachers scarcely teach with material teaching aids and essay writing is not an exception due to various factors such as unavailability of teaching materials. The scholars were also of the view that a well trained teacher should be able to design and produce materials that will meet the characteristics of the learners and should be relevant to the objective.

Table 4 reveals no significant difference in the male and female application of material teaching aids in essay writing. This shows that teachers both male and female teachers' application of material teaching aids are very poor. Most of them do not search for suitable facts, they present lessons in essay writing in abstraction, they do not select and organize relevant material teaching aids for teaching essay and they do not present materials in stages using material teaching aids.

Availability and effective application of material teaching aids - model essays, pictures, charts, maps and others in step by step teaching of essay especially in secondary schools would no doubt widen students' descriptive and intellectual abilities. It is hoped that effective material teaching aids could improve students' performance in essay writing which could be transferred to other fields of studies since essay writing is a skill in language and language is the medium through which other subjects are thought to students.

\section{Conclusion}

Essay writing is an important skill in the study of the English language. Good performance in essay writing indicates good performance in the English language. Teaching and learning of essay writing in secondary schools most often are badly taught as most teachers do not conceive it as being crucial to use material teaching aids in teaching students. They teach it in abstraction and half hazard manner which most often do not make sense to students. This may be as a result of unavailability of adequate and relevant instructional materials experienced in schools and the teachers themselves are not ready to make improvised ones. It is surprising to note that although essay writings are allocated greater part of the marks amidst other skills in English, yet, they are poorly taught or their teaching are completely avoided by most teachers. Effective application of sound instructional materials to the teaching of essay writing coupled with devotion in teaching can make abysmal performance of students in essay writing and English language become things of the past.

\section{Recommendations}

1. Careful plan of material teaching aids is no doubt very crucial to students' improvement in essay writing. This is because material teaching aids reinforces students understanding. Teachers should therefore plan, select and organize materials for teaching essay lessons. 
2. Material teaching aids should be made available in schools and teachers should prepare their lessons using teaching aids especially in essay writing.

3. School authorities should assist the teachers by providing necessary materials such as print out materials, newspapers and magazines for effective teaching in essay writing in schools.

4. The government should provide teaching aids such as audio visual and audio lingual aids and make fund available for schools.

5. Teachers, however, should be resourceful enough to fashion out simple material aids, they can use students to prepare them before the lesson starts to facilitate teaching and learning of essay writing.

\section{References}

Akinbola AO. (2009). Enhancing students' attitude towards Nigeria secondary school physics through the use of cooperative and individualistic learning strategies. Australian J. Teachers Education, 34(1), 1-9. http://dx.doi.org/10.14221/ajte.2009v34n1.1

Aluy JS. (2006). Upgrading English achievement. Zaria: Tamaza Publishing Company.

Azikiwe U. (1998). Language teaching and learning. Onitsha: Africana Fep. Publishers Ltd.

Baldeh F. (2004). Better English language teaching and learning. Nsukka: Fulladu Publishing Company.

Banjo A, \& Bisong JO. (2005). Developmental English. Ibadan: Spectrum Books Ltd.

Brown PA. (1998). Enhancing teaching and learning of English at primary school level in Nigeria. The teacher-parent factor. Tamsairi J. Education, 4(2), 40.

Chima SN., Nweke ON., Onwe A., \& Ugwuagbo O. (2005). English for intermediate students. Abakaliki: Wisdom Publishers.

Chukwu CO. (2007). Non book literacy materials impact and reading. J. Applied Literacy and Reading, 3, 98-102.

Eya P. (2006). Role of instructional materials in improving quantitative education in Nigeria. J. Education, 4(4), 54-59.

Eze PI. (2009). Effects of resource person on junior secondary students' achievement in social studies. $J$. Curriculum Studies, 16(4), 279-284.

Federal Republic of Nigeria (2004). National Policy on Education. Abuja: NRDC press.

Gaith G. (2006). Writing. American University of Beiruith.

Hornby AS. (2004). Oxford advanced learners dictionary. Oxford university press.

Obah TY. (2005). Report Writing. In H. Chukwuma, and E. Olagbunagu (eds.), English for academic purposes. Onitsha: A.F.P. Ltd.

Offorma GC. (2009). Literacy materials and functional literacy in Nigeria. J. Applied Literacy and Readily, 3(Special Edition), 12-17.

Ogbu C. (2009). Strategies for effective teaching of essay writing in junior secondary schools. J. Arts and Social Science Education, 1(1), 86-91.

Okonkwo AF. (2014). Collaborative Instructional Strategy and Essay Writing among Senior Secondary School Students. Unpublished Ph.D Thesis submitted to the Department of Arts and Social Science Education, Ebonyi State University, Abakaliki.

Otagburuagu E. (1997). Teaching and learning in writing skill in English Language: Theories, issues and practice. Onitsha: Cape Publishers International Ltd.

West African Examination Council (2006). Examiner's Report. Yaba, Lagos. 